\title{
ISBN: 978-81-932645-5-3 \\ Isolation, screening and multidrug resistance of lactose fermenting Enterobacteriaceae from clinical samples
}

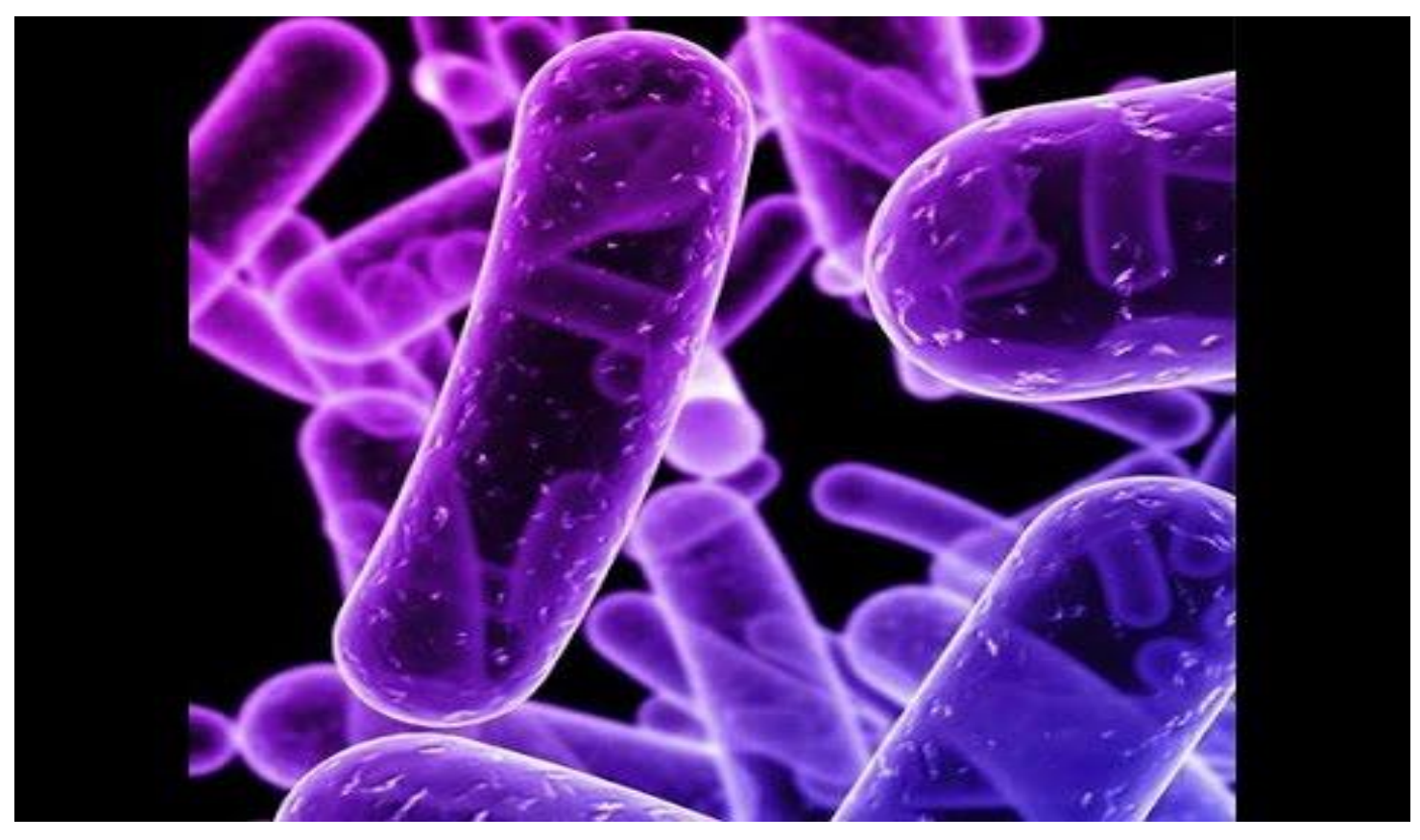

\section{Ramakrishna and Jaishanker Pillai H P}

Department of Microbiology, Gulbarga University, Kalaburagi, 585106, India

\section{DARSHAN PUBLISHERS, TAMIL NADU, INDIA}


First published in India in 2016

This edition published by Darshan publishers

http://www.darshanpublishers.com

\section{(C)2016. All rights reserved.}

Apart from any use permitted under Indian copyright law, this publication may only be reproduced, stored or transmitted, in any form, or by any means with prior permission in writing of the publishers or in the case of reprographic production in accordance with the terms of licenses issued by the Copyright Licensing Agency.

Copy Right policy is to use papers that are natural, renewable and recyclable products and made from wood grown in sustainable forests. The logging and manufacturing processes are expected to conform to the environmental regulations of the country of origin. Whilst the advice and information in this book are believed to be true and accurate at the date of going to press, neither the authors nor the publisher can accept any legal responsibility or liability for any errors or omissions that may be made. In particular, (but without limiting the generality of the preceding disclaimer) every effort has been made to check quantity of chemicals; however it is still possible that errors have been missed.

ISBN: 978-81-932645-5-3

Price: Rs: 250.00

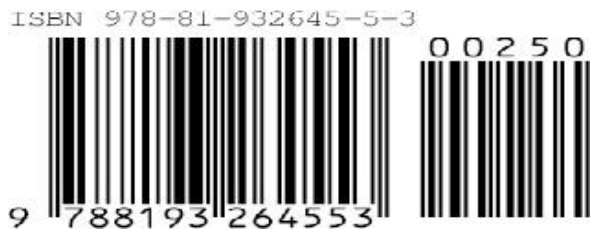

\section{Published by:}

Darshan Publishers,

8/173, Vengayapalayam, Kakkaveri, Rasipuram,

Namakkal, Tamil Nadu,

India - 637406 .

www.darshanpublishers.com

e-mail:darshanpublishers12@gmail.com

Printed by: Sri Balaji offset, Rasipuram, Namakkal, Tamil Nadu, India 


\section{About the Authors}

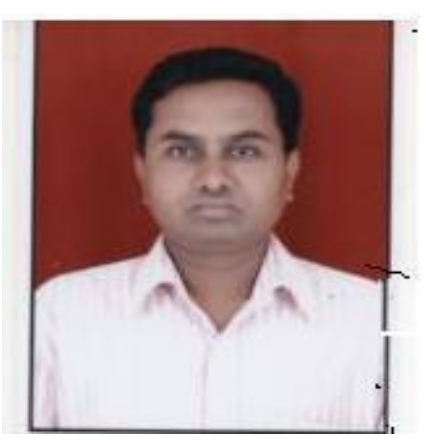

Dr. Ramakrishna Bagguri., did his M.Sc, in the year 1997-99 from Gulbarga University of Kalaburgi securing First class. He obtained his M.Phil in the year 2000 and Ph.D. in the year 2004 from Gulbarga University of Kalaburgi. He is presently serving as Assistant Professor, H.O.D and PG Coordinator at UG and PG Department of Microbiology, Government College. Sedam Road, Kalaburgi, Karanataka.

Dr. Ramakrishna Bagguri, has significantly contributed in the field of Medical Microbiology, Industrial Microbiology and Environmental Microbiology. He did research on Microbial Production of Fructose, Ethanol and also on Multidrug resistance of Salmonella typhi and Staphylococcus aureus from the Hospital clinical sample.

Dr. Ramakrishna Bagguri has published more than 20 research articles in reputed National and International journals. He has handled three research projects financed by UGC (Major and Minor) Two VGST(SPICE)Student projects are completed under his Guidance. Owing to his research contributions, he has been awarded with "Research Associate under state funding agency by Department of Biotechnology, University of Pune, Maharashtra. He received Best paper presentation awards at various National and International conferences 


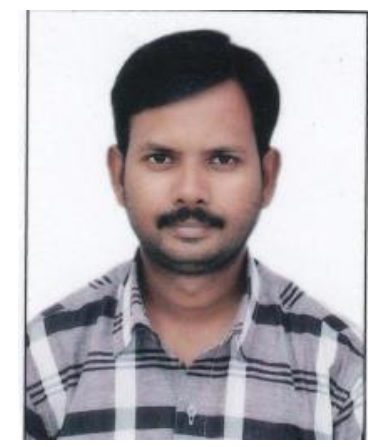

Dr.Jai Shanker Pillai H P., did his Ph. D, Microbiology in the year 2016 from Gulbarga University, Kalaburagi, Karnataka and M.Phil, Microbiology in the year 2007 from Periyar University, Salem, Tamil Nadu. He pursued his B.Ed in the year 2008 from Karnataka College of Education, Bangalore University, Bengaluru and M. Sc, Microbiology in the year 2006 from University of Mysore, Mysuru. He is presently serving as Assistant Professor in Microbiology, Department of Life Science at Kristu Jayanti College, Bengaluru. He has about 9 years of post graduatation teaching experience at University level, 5 years of research experience and 2 years of industrial experience. His research contributions are particularly in the field of Environmental Microbiologyand Agricultural Microbiology. He did research on biodegradation of solid waste molasses, synthetic rubber and synthetic textile dyes. In addition to the biodegradation he also did research on biological control of wilt and root knot disease of tomato by soil microorganisms. He has published two research articles in reputed National Journal and eighteen research articles in International journals. Considering his contributions in the field of biological scienes, Tamil Nadu Scientific Research Organization (TNSRO) awarded him "Har Gobind Khorana Young Scientist Award; 2011-12". Owing to his significant contribution, he was awarded as "Distinguish Fellow of Bose Science Society" in the year 2012-13. 